\title{
Latent Autoimmune Diabetes in Adults (LADA): Usefulness of Anti-GAD Antibody Titers and Benefit of Early Insulinization
}

artigo original

\author{
PedRo Weslley S. Rosário \\ JANICE SEPULVEDA REIS \\ TIAGO AlVARENGA FAGUNDES \\ Maria RegINA CALSOLARI \\ RICARDO AMIM \\ SaUlo CaValcanti Silva \\ SAULO PURISCH
}

Endocrinology Service, Santa Casa de Belo Horizonte, MG.

Recebido em 16/03/06

Aceito em 31/08/06

\begin{abstract}
Objective: To determine the clinical and laboratory parameters and the progression to insulin requirement in two groups of LADA patients separated according to GADA titers, and to evaluate the benefit of early insulinization in patients at high risk of premature beta-cell failure (high GADA titers). Methods: Among the diabetic adults seen at our service and screened for GADA at diagnosis, 54 were diagnosed with LADA and classified as having low $(>1 \mathrm{U} / \mathrm{ml}$ and $<17.2 \mathrm{U} / \mathrm{ml}$ ) or high $(>17.2 \mathrm{U} / \mathrm{ml}$ ) GADA titers. Fifty-four patients with type 2 diabetes (GADA-) were selected for comparison. In addition, 24 patients who had GADA titers $>20 \mathrm{U} / \mathrm{ml}$ and who were not initially insulinized were compared to 16 patients who were insulinized at diagnosis. Results: Insulin resistance was higher in the GADA- group, followed by patients with low GADA titers. BMI and the frequency of arterial hypertension, elevated triglycerides and reduced HDL cholesterol were lower in the high GADA+ group, with no difference between the GADA- or low GADA+ groups. The high GADA+ group showed a greater reduction and lower levels of C-peptide and required insulin earlier during follow-up. Patients with GADA titers $>20 \mathrm{U} / \mathrm{ml}$ and insulinized early presented no significant variation in C-peptide levels, had better glycemic control and required a lower insulin dose than patients who were insulinized later. Conclusion: We agree that patients with LADA should be differentiated on the basis of GADA titers and that patients with GADA titers $>20 \mathrm{U} / \mathrm{ml}$ benefit from early insulinization. (Arq Bras Endocrinol Metab 2007;51/1:52-58)
\end{abstract}

Keywords: GADA titers; LADA; Insulinization

\section{RESUMO}

Diabetes Autoimune Latente do Adulto (LADA): Utilidade do Título de Anticorpos Anti-GAD (GADA) e Benefício da Insulinização Precoce.

Objetivo: Determinar os parametros clínicos e laboratoriais e a progressão para a necessidade de insulina em dois grupos de pacientes com LADA, divididos de acordo com os títulos de GADA, e avaliar o benefício da insulinização precoce naqueles com risco elevado de falência prematura das células beta (títulos altos de GADA). Métodos: Dentre os pacientes adultos com diabetes (DM) seguidos em nosso serviço e rastreados para GADA no diagnóstico, 54 foram diagnosticados com LADA e classificados como tendo títulos de GADA baixos $(>1 \mathrm{U} / \mathrm{ml}$ e $<17,2 \mathrm{U} / \mathrm{ml})$ ou altos $(>17,2 \mathrm{U} / \mathrm{ml})$. A comparação foi feita com 54 pacientes selecionados com DM tipo 2 (GADA-). Além disso, 24 pacientes com títulos de GADA $>20 \mathrm{U} / \mathrm{ml}$, mas que não foram insulinizados no início, foram comparados com 16 outros que foram insulinizados desde o diagnóstico. Resultados: A resistência à insulina foi maior no grupo GADA-, seguidos por aqueles com títulos baixos de GADA. O IMC, a frequência de hipertensão arterial, os triglicérides elevados e o HDLcolesterol reduzido foram menores no grupo com títulos elevados de GADA, sem diferença entre os GADA- ou com baixos títulos de GADA. O grupo com títulos elevados de GADA mostrou uma redução maior e menores níveis de peptídeo $\mathrm{C}$, tendo requerido insulina mais precocemente durante $\mathrm{O}$ seguimento. Pacientes com títulos de GADA > $20 \mathrm{U} / \mathrm{ml}$ e precocemente insulinizados não apresentaram variações significantes nos níveis de peptídeo C, tiveram melhor controle glicêmico e requereram doses mais baixas de insulina do que aqueles que foram insulinizados mais tardiamente. Conclusão: Nós concordamos que pacientes com LADA devem ser diferenciados com base nos títulos de GADA e que aqueles com títulos > 20 $\mathrm{U} / \mathrm{ml}$ beneficiam-se de insulinização precoce. (Arq Bras Endocrinol Metab 2007;51/1:52-58)

Descritores: Títulos de GADA; LADA; Insulinização 
L ATENT AUTOIMMUNE DIABETES in adults (LADA) is a form of autoimmune diabetes that affects adult patients who do not require insulin at diagnosis and are positive for autoantibodies against beta cells [antiglutamic acid decarboxylase (GADA) and anti-islet cell (ICA) antibodies], and is associated with premature beta-cell failure $(1,2)$. In general, LADA differs from type 2 diabetes in terms of metabolic syndrome, genetic characteristics, and the progression to insulin requirement (2-6). However, some patients show features similar to type 2 diabetes, which characterize a distinct form, LADA type 2 (7) or type 1.5 diabetes (8).

Antibodies are the main predictors of functional deterioration of beta cells (2), especially at high titers $(2,4,7,9)$ and when present in combination (GADA and ICA) $(3,6,7)$. A prospective multicenter study has shown that patients with LADA benefit from early insulinization, but this gain was restricted to those with high GADA titers and who still presented a good functional reserve of beta cells $(10,11)$.

In the present study, we determined the clinical and laboratory parameters and the progression to insulin requirement in two groups of LADA patients distinguished based on GADA titers and evaluated the benefit of early insulinization in patients at high risk of premature beta-cell failure (high GADA titers).

\section{PATIENTS AND METHODS}

Among the diabetic adults (> 35 years) seen at our service before 2002 and screened for GADA at diagnosis (no routine ICA and IA-2A analyses were performed) (1), 54 were diagnosed with LADA (individuals not requiring insulin for at least 6 months after diagnosis and GADA+) $(3,4)$ and classified as having low $(>1 \mathrm{U} / \mathrm{ml}$ and $<17.2$ $\mathrm{U} / \mathrm{ml}$ ) or high $(>17.2 \mathrm{U} / \mathrm{ml}$ ) GADA titers. According to another study that defined the cut-off based on the stratification of GADA titers (4), we also established the cutoff $(17.2 \mathrm{U} / \mathrm{ml})$ as the value corresponding to the median GADA titers at the time of diagnosis, which showed no normal distribution in the LADA group. Patients with type 1 diabetes (requiring insulin immediately after diagnosis) $(1,3,8,12)$ were excluded.

Although the onset of LADA occurs in many cases between 25 and 35 years (2), previous investigations (1,3$5,7,12)$ have established a limit of 35 years as done in the present study.

Fifty-four patients with type 2 diabetes (GADA-), matched for gender and age with the LADA group, were selected for comparison. Patients were selected by separating type 2 diabetic patients older than 35 years and GADA- at diagnosis. For each LADA case detected, one patient of the same gender and with similar age was selected from this group. The lack of a significant difference in these parameters between GADA- and LADA patients validated this selection. The characteristics of the patients are shown in table 1 .

The treatment protocol initially consisted of nonpharmacological measures and monotherapy with oral antidiabetic drugs in all patients. During follow-up, the patients were submitted to clinical and laboratory tests every 3 months for glycemic control and treatment adaptation. The daily drug dose was increased and/or a new medication was added, in addition to the reinforcement of nonpharmacological measures when $\mathrm{HbAlc}>7 \%$. The drug dose was reduced when $\mathrm{HbAlc}<6 \%$. Insulin was introduced at sustained $\mathrm{HbAlc}$ levels $>7 \%$ after a period of 12 months of combined use of $\geq 1700 \mathrm{mg}$ metformin and $\geq 15 \mathrm{mg}$ glibenclamide per day (13), in addition to non-pharmacological therapy.

On the basis of the preliminary data of a multicenter study showing the benefit of early insulinization in patients with high GADA titers (11), all of our patients with GADA titers $>20 \mathrm{U} / \mathrm{ml}$ have been insulinized since 2002. This permitted the comparison of two groups: $24 / 54$ patients diagnosed before 2002 who had GADA titers > $20 \mathrm{U} / \mathrm{ml}$ and who were not initially insulinized (group 1 ) and 16 patients with GADA titers $>20 \mathrm{U} / \mathrm{ml}$ who were insulinized at diagnosis (group 2) as done since 2002. In group 2, the insulin dose (initial dose $0.2 \mathrm{U} / \mathrm{kg} /$ day) was adjusted according to glycemic control and these patients did not receive oral anti-hyperglycemic drugs. In 2002, all patients of group 1 were insulinized and the oral medications were discontinued irrespective of glycemic control. The data refer to the follow-up until that year. The initial characteristics of the patients with GADA titers $>20 \mathrm{U} / \mathrm{ml}$ are shown in table 2 .

Eleven patients were lost to follow-up [GADA- (6), low GADA titers (3), high GADA titers (2)].

This study was approved by the Research Ethics Committee of the Institution.

\section{Laboratory assessment}

GADA were detected with commercial immunoprecipitation assays using 125 I-labeled human recombinant GAD (RSR Ltd., Cardiff, UK) (14). The lower detection limit was 0.1 $\mathrm{U} / \mathrm{ml}$. The reference value was $<1.0 \mathrm{U} / \mathrm{ml}$. These cut-off levels for positivity were established using the $99^{\text {th }}$ percentile of the control group (100 non-diabetic, non-glucose intolerant individuals without known autoimmune disease and no family history of diabetes). This assay was previously evaluated by the laboratory, and the intra-assay and interassay coefficients of variation were 3.1 and $3.5 \%$, respectively, for normal reference values. Sensitivity was $80 \%$ for type 1 diabetic patients with a recent diagnosis (15). The assay kits achieved good discrimination between cases and controls with an area under the curve and 90\% adjusted sensitivity above the $75^{\text {th }}$ percentile for both, as recommended for a good quality assay (16). TPOAb were assayed by chemiluminescence, with a level $>15 \mathrm{U} / \mathrm{ml}$ being considered positive. 
Table 1. Characteristics of the patients diagnosed before 2002.

\begin{tabular}{|c|c|c|c|}
\hline & $\begin{array}{l}\text { GADA negative } \\
\text { (DM 2) }\end{array}$ & $\begin{array}{l}\text { GADA } \\
<17.2 \mathrm{U} / \mathrm{ml}\end{array}$ & $\begin{array}{c}\text { GADA } \\
>17.2 \mathrm{U} / \mathrm{ml}\end{array}$ \\
\hline \multicolumn{4}{|l|}{ At diagnosis } \\
\hline Number of patients & 54 & 27 & 27 \\
\hline Gender (male:female) & $31: 23$ & $15: 12$ & 16:11 \\
\hline Age (years) & $42.1 \pm 3$ & $40.2 \pm 3.1$ & $40.6 \pm 3.5$ \\
\hline BMI $\left(\mathrm{kglm}^{2}\right) \dagger$ & $28.9 \pm 2.9$ & $28.8 \pm 3$ & $24.9 \pm 3.5$ \\
\hline Fasting glycemia (mmolll) & $9.8 \pm 2.9$ & $10.2 \pm 2.5$ & $10.9 \pm 2.4$ \\
\hline $\mathrm{HbA1c}(\%)$ & $8 \pm 0.75$ & $7.9 \pm 1.1$ & $8.05 \pm 0.95$ \\
\hline C-peptide (nmollI) & $0.65 \pm 0.19$ & $0.66 \pm 0.25$ & $0.6 \pm 0.3$ \\
\hline Arterial hypertension (\%) † & 65 & 55.5 & 18.5 \\
\hline Triglycerides > $1.69 \mathrm{mmol} / \mathrm{l}(\%) \dagger$ & 70 & 52 & 18.5 \\
\hline HDL cholesterol $<1.03$ (men) and $<1.29 \mathrm{mmol} / \mathrm{l}$ (women) (\%) $\dagger$ & 70 & 63 & 26 \\
\hline Presence of TPO antibodies (\%) $\dagger$ & 5.5 & 11 & 37 \\
\hline $\mathrm{TSH} \geq 5 \mathrm{mlU} / \mathrm{l}(\%)$ & 7.4 & 11 & 26 \\
\hline HOMA-IR (pmolll x nmollI) § & $4.1 \pm 1.9$ & $2.95 \pm 2$ & $1.96 \pm 1.2$ \\
\hline \multicolumn{4}{|l|}{ Last assessment of the study } \\
\hline Number of patients & 48 & 25 & 25 \\
\hline Follow-up (months) & $37 \pm 20$ & $36 \pm 16$ & $35 \pm 18$ \\
\hline Fasting glycemia (mmolll) & $8 \pm 2.7$ & $7.5 \pm 2.9$ & $8 \pm 3$ \\
\hline $\mathrm{HbA1c}(\%)$ & $7.1 \pm 1.5$ & $7.2 \pm 1.7$ & $7.1 \pm 1.4$ \\
\hline C-peptide (nmollI) † & $0.47 \pm 0.27$ & $0.43 \pm 0.2$ & $0.29 \pm 0.25$ \\
\hline C-peptide reduction (\%) † & $23 \pm 9$ & $22 \pm 10$ & $51 \pm 19$ \\
\hline C-peptide $<0.3$ nmolll (ref. 20) (\%) $†$ & 4.2 & 8 & 44 \\
\hline Became GADA negative (\%) & & $24 \%$ & $0 \%$ \\
\hline
\end{tabular}

† Low GADA titers versus DM 2 ( $p>0.05$ ) and low GADA titers versus high GADA titers $(p<0.05)$.

$\S$ Low GADA titers versus DM $2(p<0.05)$ and low GADA titers versus high GADA titers $(p<0.05)$.

Table 2. Characteristics of the patients with GADA titers $>20 \mathrm{U} / \mathrm{ml}$ at diagnosis.

\begin{tabular}{lcc}
\hline & Non-insulinized (n= 23) & Insulinized (n= 15) \\
Gender (male:female) & $13: 10$ & $9: 6$ \\
Age (years) & $40.8 \pm 3.7$ & $40 \pm 2.7$ \\
BMI (kg/m ${ }^{2}$ & $24.8 \pm 3.4$ & $25 \pm 2.1$ \\
HbA1c $(\%)$ & $7.9 \pm 0.7$ & $8.1 \pm 1.1$ \\
Fasting glycemia (mmol/l) & $10.8 \pm 2.3$ & $10.2 \pm 2.7$ \\
GADA levels (U/ml) & $33 \pm 4.7$ & $38 \pm 5.6$ \\
C-peptide levels $(\mathrm{nmol} / \mathrm{l})$ & $0.59 \pm 0.31$ & $0.55 \pm 0.27$ \\
\hline
\end{tabular}

$p>0.05$ for all parameters.

HbAlc was measured by HPLC (normal 4-6\%). Cpeptide was measured by immunofluorimetry (reference $0.35-1.65 \mathrm{nmol} / \mathrm{l}$ ) during fasting on two occasions (interval of one week), with a coefficient of variation of $15 \%$. Insulin resistance was estimated by HOMA-IR (calculated based on fasting glycemia and insulinemia in the same sample) (17). HOMA-IR was determined in three samples at 5-min intervals (18) and showed a coefficient of variation of $13 \%$. Oral drugs or insulin were withdrawn 24 h before (17) and C-peptide and HOMA-IR measurements were made at fasting glycemia levels $<8.5 \mathrm{mmol} / \mathrm{l}$ in all patients. The results are reported as the mean of these measurements.

\section{Statistical analysis}

The results are expressed as means \pm SD unless otherwise indicated. Differences in continuous variables between groups were estimated using the nonparametric MannWhitney U test. For dichotomous variables, Fisher's exact test was used. ANOVA was used to determine variations in the same group (at diagnosis and at the end of the study). Logistic regression analysis was applied to evaluate potential confounding covariables (gender, age, BMI, HbAlc, fasting glycemia). A p-value $<0.05$ was considered to be significant. 


\section{RESULTS}

HOMA-IR was higher in the GADA- group, followed by patients with low GADA titers. Patients with high GADA titers showed lower insulin resistance even after multivariate analysis (table 1 ). BMI and the frequency of arterial hypertension, elevated triglycerides [ $>1.69$ $\mathrm{mmol} / \mathrm{l}(150 \mathrm{mg} / \mathrm{dl})]$ and reduced HDL cholesterol $[<1.03 \mathrm{mmol} / 1(40 \mathrm{mg} / \mathrm{dl})$ in women and $<1.29$ $\mathrm{mmol} / \mathrm{l}(50 \mathrm{mg} / \mathrm{dl})$ in men] were lower in the high GADA+ group, with no difference between the GADA- or low GADA+ groups (table 1). The high GADA+ group showed a greater reduction and lower levels of C-peptide (table 1) and required insulin earlier during follow-up (figure 1). No difference in these parameters was observed between the low GADA+ and GADA- groups. None of the six patients with low GADA titers at diagnosis who became GADA- during follow-up required insulin versus 3/19 (16\%) patients who continued to be GADA+.

Figure 1 shows the cumulative percentage of patients who progressed to insulin requirement, excluding those who were lost to follow-up after the diagnosis (four in the GADA+ group and six in the GADA- group).

With respect to early insulinization of diabetic patients with GADA titers > $20 \mathrm{U} / \mathrm{ml}$, patients insulinized early (group 2) presented no significant variation in $\mathrm{C}$-peptide levels, indicating the functional preservation of beta cells, had better glycemic control (lower fasting glycemia and HbAlc) and required a lower insulin dose than patients who were insulinized later (group 1) (table 3 ). In group 1, no difference in insulin requirement (50\% versus $53 \%$ ),

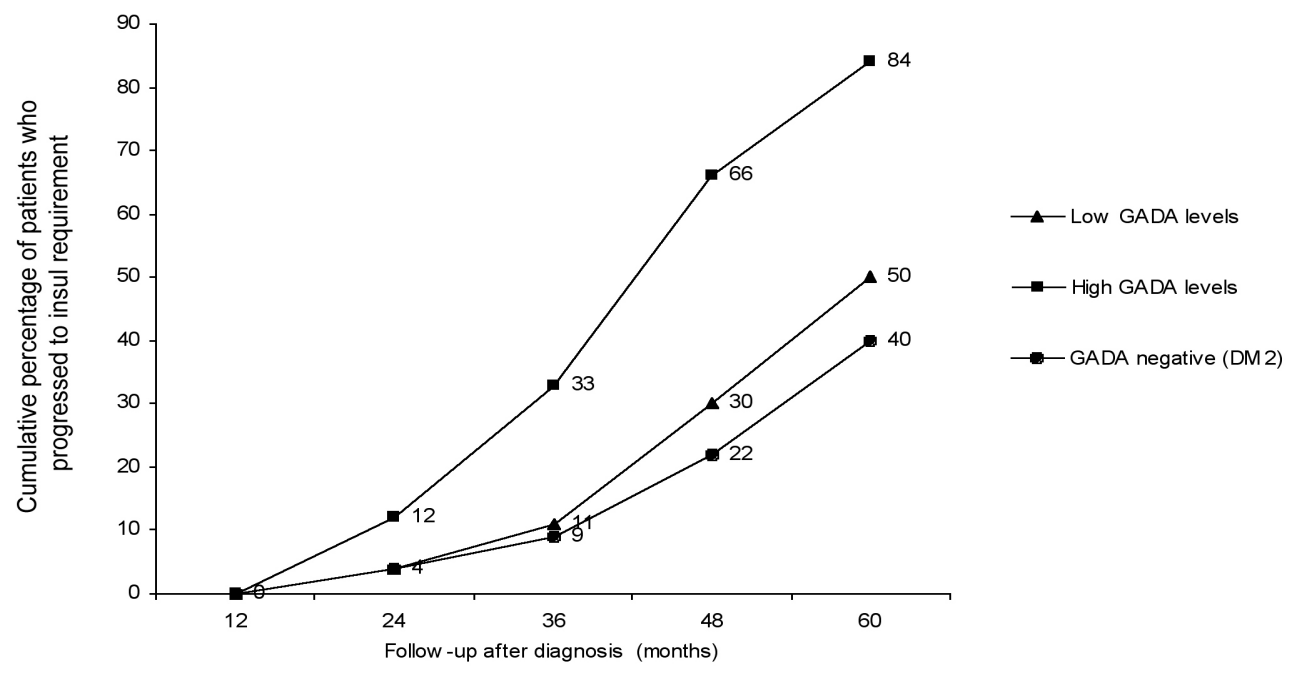

\begin{tabular}{|c|c|c|c|c|c|}
\hline Group / follow-up & 12 months & 24 months & 36 months & 48 months & 60 months \\
\hline Low GADA titers & $0 / 25$ & $1 / 25(4 \%)$ & $2 / 18(11 \%)$ & $3 / 10(30 \%)$ & $3 / 6(50 \%)$ \\
\hline High GADA titers & $0 / 25$ & $3 / 24(12 \%)$ & $6 / 18(33 \%)$ & $10 / 15(66 \%)$ & $11 / 13(84 \%)$ \\
\hline GADA negative (DM 2) & $0 / 48$ & $2 / 48(4 \%)$ & $3 / 34(9 \%)$ & $4 / 18(22 \%)$ & $4 / 10(40 \%)$ \\
\hline
\end{tabular}

Figure 1. Cumulative percentage of patients diagnosed before 2002 who progressed to insulin requirement.

Table 3. Characteristics of the patients with GADA titers $>20 \mathrm{U} / \mathrm{ml}$ upon last assessment.

\begin{tabular}{|c|c|c|}
\hline & Non-insulinized & Insulinized \\
\hline C-peptide $(\mathrm{nmol} / \mathrm{l}) *$ & $0.28 \pm 0.23$ & $0.51 \pm 0.3$ \\
\hline C-peptide $<0.3 \mathrm{mmol} / \mathrm{l}(12) *$ & $48 \%$ & $15 \%$ \\
\hline C-peptide variation (\%) & $50 \pm 17(p<0.001)$ & non-significant \\
\hline Insulin requirement & $52 \%$ & - \\
\hline Required insulin dose * & $0.7 \mathrm{U} / \mathrm{kg} / \mathrm{day}$ & $0.32 \mathrm{U} / \mathrm{kg} / \mathrm{day}$ \\
\hline Severe hypoglycemia & 0 & 0 \\
\hline Follow-up after diagnosis (years) & $3 \pm 1.5$ & $2.8 \pm 1.3$ \\
\hline Fasting glycemia $(\mathrm{mmol} / \mathrm{l}) *$ & $7.9 \pm 3.1$ & $6.5 \pm 2.8$ \\
\hline $\mathrm{HbA} 1 \mathrm{c}(\%) *$ & $7.1 \pm 1.3$ & $6.5 \pm 1.05$ \\
\hline
\end{tabular}

* $p<0.05$. 
C-peptide reduction $(47 \pm 17 \%$ versus $52 \pm 14 \%)$ or C-peptide $<0.3 \mathrm{mmol} / \mathrm{l}$ (19) (47\% versus $50 \%$ ) was observed between patients who initially received metformin $(n=8)$ and those starting therapy with sulfonylurea $(\mathrm{n}=15)$, but all patients had received sulfonylurea for at least 12 months before evaluation by this study.

\section{DISCUSSION}

In LADA, insulin resistance can coexist with insulin deficiency (20). Our study confirms that, in addition to BMI (8), GADA titers help in the differentiation of patients with associated insulin resistance, who usually present low titers. The clear difference between diabetic patients with high and low antibody titers in relation to components of the metabolic syndrome demonstrated in other series $(4,21,22)$ was confirmed here. However, the difference between patients with low GADA levels and type 2 diabetics is not completely understood. In the present study, higher insulin resistance was observed in type 2 diabetic patients. Lin et al. (22) observed a higher frequency of hyperlipidemia in these patients, and Tuomi et al. (4) also demonstrated differences in waist-hip ratio, triglycerides and blood pressure between these two groups of patients.

Beta-cell function (generally evaluated based on C-peptide levels) is significantly compromised in patients with high GADA levels (4,21-24). However, we demonstrated that basal C-peptide levels did not differ between patients with LADA and type 2 diabetics, a finding that can be attributed to the fact that the patients were evaluated at diagnosis when beta cells still show good functional capacity in LADA, a condition that is more characterized by a premature deterioration of beta-cell function than early installation of insufficiency. This hypothesis was supported by the observation that patients with high GADA titers showed a greater reduction and lower levels of C-peptide during follow-up. In fact, a difference in C-peptide levels between patients with and without autoantibodies may not be detected early (25), especially during basal measurements (20). Stimulation tests might provide a more adequate assessment of the functional reserve of beta cells in patients with a recent diagnosis (20).

The high GADA+ patients progressed early to insulin requirement, in agreement with other studies $(2,4,10,11,21,22,24,26,27)$. Low GADA+ and GADA- patients were similar in terms of beta-cell function and insulin requirement. However, the progression of patients with low GADA titers to insulin requirement may not be the same as observed for type 2 diabetics. Takino et al. (9) found that 33\% of patients with low GADA titers $(<20 \mathrm{U} / \mathrm{ml})$ and a history of diabetes $<5$ years required insulin treatment within 2 years of follow-up. Hosszufalusi et al. (3) did not demonstrate a difference in GADA titers between the LADA group (not requiring insulin) and patients with adult-onset type 1 diabetes who rapidly progressed to insulin requirement (at diagnosis or within a short follow-up period). In addition, the difference between low GADA and GADA- patients may not be recognized within a medium term follow-up period ( 5 years) and only becomes evident in the long term (12 years) (28), compatible with a slowly progressing autoimmune process which results in late beta-cell failure but still earlier than in type 2 diabetes. The predominance of antibodies directed at the $\mathrm{COOH}$-terminal portion of glutamic acid decarboxylase (GAD-CAb) is associated with rapid functional deterioration of beta cells, a phenotype resembling type 1 diabetes, whereas GADA directed only at the $\mathrm{N}$-terminal portion or at epitopes within the molecule determine a phenotype similar to that observed in GADA- diabetics (29). Interestingly, a strong correlation exists between high GADA titers and the predominance of GAD-CAb $(30,31)$.

It is interesting to note that in the present study approximately $20 \%$ of the patients with low GADA titers became GADA- within 3 years. The possible disappearance of GADA is supported by studies that clearly demonstrate a lower prevalence of these antibodies in patients diagnosed many years before $(9,25,32)$. The disappearance of low GADA titers has been reported previously (28,33-36), but at a lower percentage than that observed in the present study. GADA present at low titers and not associated with other anti-islet antibodies, which disappear subsequently, may represent a false-positive result of the assay. However, the subjects evaluated as controls in the present study did not present GADA titers > 1 $\mathrm{U} / \mathrm{ml}$, indicating the specificity of this assay. Another hypothesis is that these patients present a less intense autoimmune process accompanied by possible shortterm remission, so that they do not progress to insulin requirement after 3 years.

TPOAb are known to be more frequent in GADA+ than in GADA- adult diabetics (37). We showed here that high GADA titers identified a subgroup of patients with a high prevalence of anti- 
thyroid antibodies. A predominance of GAD-CAb is also associated with a higher prevalence of TPOAb in patients with LADA (30). These data favor the hypothesis that extra-pancreatic autoimmunity is more notable in patients who are phenotypically closer to type 1 diabetics and who progress to early insulin requirement.

The use of insulin reduces beta-cell activity, decreasing antigen expression and the autoimmune process, with a consequent reduction in the destruction of these cells; sulfonylureas have an opposite effect and metformin has a neutral effect on this process (1). This rationale forms the basis for the use of insulin in patients with LADA in an attempt to preserve beta cells. In fact, initial studies have shown that insulin induces the disappearance of ICA antibodies, whereas these antibodies persist in patients treated with sulfonylureas, a finding possibly reflecting what occurs during the autoimmune process in the islets in response to the two therapies $(38,39)$. Early insulinization does not seem to benefit all patients with adult autoimmune diabetes, with functional preservation of beta cells only being achieved in those with high GADA titers and preserved C-peptide $(10,11)$, a fact supporting the importance of the distinction from LADA based on GADA titers. These data were confirmed in the present series. Measurement of GADA at the time of diagnosis permitted intervention during a phase when the beta cells still presented a good secretory capacity. In addition, the selection of patients at high risk for premature betacell failure (high GADA titers) permitted the easy differentiation between insulinized and conventionally treated patients even over a short follow-up period.

Experimental studies indicate that glitazones might be promising for the preservation of beta cells in type 1 diabetics and also in LADA (40). In fact, a pilot study on patients with LADA has shown that a combination of rosiglitazone and insulin was associated with the maintenance of C-peptide levels, whereas a decrease was observed in patients treated only with insulin (41).

\section{CONCLUSIONS}

We agree that patients with LADA should be differentiated on the basis of autoantibody titers (7) rather than BMI (8), which is less predictive of the need for insulin $(2,42)$ and does not predict the beneficial effect of insulinization $(10,11)$. We suggest caution with the assumption that LADA together with low GADA levels is the same as type 2 diabetes. In view of the demonstration that patients with high GADA titers benefit from early insulinization, measurement of GADA is recommended for apparently type 2 diabetic patients. The early diagnosis of LADA, when the insulin-secretory capacity is still good, and the adequate selection of high-risk patients, better provided by high GADA titers, permit the identification of patients that should be submitted to early insulinization.

\section{REFERENCES}

1. Pozzilli P, Di Mario U. Autoimmune diabetes not requiring insulin at diagnosis (latent autoimmune diabetes of the adult): definition, characterization, and potential prevention. Diabetes Care 2001;24:1460-7.

2. Turner R, Stratton I, Horton V, Manley S, Zimmet P, Mackay IR, et al. UKPDS 25: autoantibodies to islet-cell cytoplasm and glutamic acid decarboxylase for prediction of insulin requirement in type 2 diabetes. UK Prospective Diabetes Study Group. Lancet 1997;350:1288-93.

3. Hosszufalusi N, Vatay A, Rajczy K, Prohaszka Z, Pozsonyi E, Horvath $L$, et al. Similar genetic features and different islet cell autoantibody pattern of latent autoimmune diabetes in adults (LADA) compared with adult-onset type 1 diabetes with rapid progression. Diabetes Care 2003;26:452-7.

4. Tuomi T, Carlsson A, Li H, Isomaa B, Miettinen A, Nilsson A, et al. Clinical and genetic characteristics of type 2 diabetes with and without GAD antibodies. Diabetes 1999;48:150-7.

5. Isomaa B, Almgren $P$, Henricsson M, Taskinen MR, Tuomi T, Groop L, et al. Chronic complications in patients with slowly progressing autoimmune type 1 diabetes (LADA). Diabetes Care 1999;22:1347-53.

6. Zinman B, Kahn SE, Haffner SM, O'Neill MC, Heise MA, Freed MI (ADOPT Study Group). Phenotypic characteristics of GAD antibody-positive recently diagnosed patients with type 2 diabetes in North America and Europe. Diabetes 2004; 53:3193-200.

7. Lohmann T, Kellner K, Verlohren HJ, Krug J, Steindorf J, Scherbaum WA, et al. Titre and combination of ICA and autoantibodies to glutamic acid decarboxylase discriminate two clinically distinct types of latent autoimmune diabetes in adults (LADA). Diabetologia 2001;44:1005-10.

8. Palmer JP, Hirsch IB. What's in a name: Latent autoimmune diabetes of adults, type 1.5, adult-onset, and type 1 diabetes. Diabetes Care 2003;26:536-8.

9. Takino H, Yamasaki H, Abiru N, Sera Y, Abe T, Kawasaki E, et al. Antibodies to GAD in Japanese patients classified as type 2 diabetes at diagnosis. High titre of GADAb is a predictive marker for early insulin treatment - report of west Japan (Kyushu, Yamaguchi, Osaka) study for GADAb(+) diabetes. Diabet Med 2002;19:730-4.

10. Maruyama T, Shimada A, Kanatsuka A, Kasuga A, Takei I, Yokoyama J, et al. Multicenter prevention trial of slowly progressive type 1 diabetes with small dose of insulin (the Tokyo study): preliminary report. Ann $\mathbf{N}$ Acad Sci 2003:1005:362-9.

11. Kobayashi T, Maruyama T, Shimada A, Kasuga A, Kanatsuka A, Takei I, et al. Insulin intervention to preserve beta cells in slowly progressive insulin-dependent (type 1) diabetes mellitus. Ann N Y Acad Sci 2002;958:117-30.

12. Rosário PW, Reis JS, Amim R, Fagundes TA, Calsolari MR, Silva SC, et al. Comparison of clinical and laboratory characteristics between adult-onset type 1 diabetes and latent autoimmune diabetes in adults. Diabetes Care 2005;28:1803-4. 
13. Prando R, Cheli V, Melga P, Giusti R, Ciuchi E, Odetti P. Is type 2 diabetes a different disease in obese and nonobese patients? Diabetes Care 1998;21:1680-5.

14. Powell M, Prentice L, Asawa T, Kato R, Sawicka J, Tanaka H, et al. Glutamic acid decarboxylase autoantibody assay using 125l-labelled recombinant GAD65 produced in yeast. Clin Chim Acta 1996;256:175-88.

15. Pardini VC, Mourão DM, Nascimento PD, Vivolo MA, Ferreira SR, Pardini H. Frequency of islet cell autoantibodies (IA-2 and $\mathrm{GAD}$ ) in young Brazilian type 1 diabetes patients. Braz J Med Biol Res 1999;32:1195-8.

16. Bingley PJ, Bonifacio E, Mueller PW. Diabetes antibody standardization program: First assay proficiency evaluation. Diabetes 2003;52:1128-36.

17. Emoto M, Nishizawa Y, Maekawa K, Hiura Y, Kanda H, Kawagishi $\mathrm{T}$, et al. Homeostasis model assessment as a clinical index of insulin resistance in type 2 diabetic patients treated with sulfonylureas. Diabetes Care 1999;22:818-22.

18. Bonora E, Targher G, Alberiche M, Bonadonna RC, Saggiani F, Zenere MB, et al. Homeostasis model assessment closely mirrors the glucose clamp technique in the assessment of insulin sensitivity: studies in subjects with various degrees of glucose tolerance and insulin sensitivity. Diabetes Care 2000;23:57-63.

19. Hother-Nielsen O, Faber O, Sorensen NS, Beck-Nielsen H. Classification of newly diagnosed diabetic patients as insulinrequiring or non-insulin-requiring based on clinical and biochemical variables. Diabetes Care 1988;11:531-7.

20. Carlsson A, Sundkvist G, Groop L, Tuomi T. Insulin and glucagon secretion in patients with slowly progressing autoimmune diabetes (LADA). J Clin Endocrinol Metab 2000;85:76-80.

21. Borg H, Gottsater A, Landin-Olsson M, Fernlund $P$, Sundkvist G. High levels of antigen-specific islet antibodies predict future beta-cell failure in patients with onset of diabetes in adult age. J Clin Endocrinol Metab 2001;86:3032-8.

22. Li X, Yang L, Zhou Z, Huang G, Yan X. Glutamic acid decarboxylase 65 autoantibody levels discriminate two subtypes of latent autoimmune diabetes in adults. Chin Med J (Engl) 2003;116:1728-32.

23. Hamaguchi $K$, Kimura A, Kusuda $Y$, Yamashita T, Yasunami $M$, Takahasi $M$, et al. Clinical and genetic characteristics of GAD-antibody positive patients initially diagnosed as having type 2 diabetes. Diabetes Res Clin Pract 2004;66:163-71.

24. Gottsater A, Landin-Olsson M, Lernmark A, Fernlund $P$, Sundkvist G, Hagopian WA. Glutamate decarboxylase antibody levels predict rate of beta-cell decline in adult-onset diabetes. Diabetes Res Clin Pract 1995;27:133-40.

25. Kasuga A, Maruyama T, Ozawa Y, Takei I, Falorni A, Lernmark $A$, et al. Antibody to the $M(r) 65,000$ isoform of glutamic acid decarboxylase are detected in non-insulin-dependent diabetes in Japanese. J Autoimmun 1996;9:105-11.

26. Kasuga A, Maruyama T, Nakamoto S, Ozawa $Y$, Suzuki $Y$, Saruta T. High-titer autoantibodies against glutamic acid decarboxylase plus autoantibodies against insulin and IA-2 predicts insulin requirement in adult diabetic patients. $J$ Autoimmun 1999;12:131-5.

27. Takeda H, Kawasaki E, Shimizu I, Konoue E, Fujiyama M, Murao S, et al;Ehime Study. Clinical, autoimmune, and genetic characteristics of adult-onset diabetic patients with GAD autoantibodies in Japan (Ehime Study). Diabetes Care 2002;25:995-1001.

28. Borg H, Gottsater A, Fernlund P, Sundkvist G. A 12-year prospective study of the relationship between islet antibodies and beta-cell function at and after the diagnosis in patients with adult-onset diabetes. Diabetes 2002;51:1754-62.
29. Falorni A, Calcinaro F. Autoantibody profile and epitope mapping in latent autoimmune diabetes in adults. Ann $\mathbf{N}$ Y Acad Sci 2002;958:99-106.

30. Falorni A, Gambelunghe G, Forini F, Kassi G, Cosentino A Candeloro $\mathrm{P}$, et al. Autoantibody recognition of $\mathrm{COOH}$ terminal epitopes of GAD65 marks the risk for insulin requirement in adult-onset diabetes mellitus. J Clin Endocrinol Metab 2000;85:309-16.

31. Ziegler B, Strebelow M, Rjasanowski I, Schlosser M, Ziegler M. A monoclonal antibody-based characterization of autoantibodies against glutamic acid decarboxylase in adults with latent autoimmune diabetes. Autoimmunity 1998;28:61-8.

32. Tsuruoka A, Matsuba I, Toyota T, Isshiki G, Nagataki S, Ikeda Y. Antibodies to GAD in Japanese diabetic patients: a multicenter study. Diabetes Res Clin Pract 1995;28:191-9.

33. Fukui M, Nakamura N, Nakano K, Kajiyama S, Matsuo S, Obayashi $H$, et al. HLA-associated cellular response to GAD in type 2 diabetes with antibodies to GAD. Endocrine J 2000;47:753-61.

34. Kobayashi T, Nakanishi K, Okubo M, Murase T, Kosaka K. GAD antibodies seldom disappear in slowly progressive IDDM (Letter). Diabetes Care 1996;19:1031.

35. Decochez K, Tits J, Coolens JL, Van Gaal L, Krzentowski G, Winnock $F$, et al. High frequency of persisting or increasing islet-specific autoantibody levels after diagnosis of type 1 diabetes presenting before 40 years of age. The Belgian Diabetes Registry. Diabetes Care 2000;23:838-44.

36. Niskanen LK, Tuomi T, Karjalainen J, Groop LC, Uusitupa MI. GAD antibodies in NIDDM. Ten-year follow-up from the diagnosis. Diabetes Care 1995;18:1557-65.

37. Gambelunghe G, Forini F, Laureti S, Murdolo G, Toraldo G, Santeusanio $F$, et al. Increased risk for endocrine autoimmunity in Italian type 2 diabetic patients with GAD65 autoantibodies. Clin Endocrinol (Oxf) 2000;52:565-73.

38. Kobayashi T, Nakanishi K, Murase T, Kosaka K. Small doses of subcutaneous insulin as a strategy for preventing slowly progressive beta-cell failure in islet cell antibody-positive patients with clinical features of NIDDM. Diabetes 1996;45:622-6.

39. Cabrera-Rode E, Perich P, Diaz-Horta O, Tiberti C, Molina G, Arranz C, et al. Slowly progressing type 1 diabetes: persistence of islet cell autoantibodies is related to glibenclamide treatment. Autoimmunity 2002;35:469-74.

40. Beales PE, Pozzilli P. Thiazolidinediones for the prevention of diabetes in the non-obese diabetic (NOD) mouse: implications for human type 1 diabetes. Diab Metab Res Rev 2002;18:114-7.

41. Zhou Z, Li X, Huang G, Peng J, Yang L, Yan X, et al. Rosiglitazone combined with insulin preserves islet beta cell function in adult-onset latent autoimmune diabetes (LADA). Diab Metab Res Rev 2005;21:203-8.

42. Gottsater A, Landin-Olsson M, Lernmark A, Fernlund $P$, Sundkvist $G$. Islet cell antibodies are associated with $\beta$-cell failure also in obese adult onset diabetic patients. Acta Diabetol 1994;31:226-31.

\section{Endereço para correspondência:}

Pedro Weslley Souza Rosário

Centro de Estudos e Pesquisa

Clínica de Endocrinologia e Metabologia (CEPCEM)

Av. Francisco Sales $1111,5^{\circ}$ andar, ala D

30150-221 Belo Horizonte, MG

Fax: (31) 3213-0836

E-mail: pedrorosario@globo.com 